\title{
STATE-OF-THE-ART EMC REGULATION AND CONFORMITY OF PRODUCTS IN INDONESIA
}

\section{KONDISI TERKINI REGULASI EMC DAN KESESUAIAN PRODUK DI INDONESIA}

\author{
I. Inayaturohman ${ }^{1}$, D. Hamdani ${ }^{2}$, D. Darwanto ${ }^{3}$ \\ ${ }^{1} \mathrm{~B} 4 \mathrm{~T}$, Ministry of Industry, Bandung, Indonesia \\ ${ }^{1,2,3}$ Power Engineering Division, School of Electrical Engineering and Informatics, \\ Institut Teknologi Bandung, Bandung, Indonesia \\ Email: ${ }^{1}$ b4t@b4t.go.id, ${ }^{2}$ deny@power.ee.itb.ac.id, ${ }^{3}$ darwanto@hv.ee.itb.ac.id
}

Diterima: 6 November 2014 Direvisi: 2 Desember 2014 Disetujui: 23 Desember 2014

\begin{abstract}
ABSTRAK
Kompatibilitas elektromagnetik (EMC) dapat dianggap kemampuan suatu peralatan yang tetap dapat berfungsi secara baik pada lingkungan Elektromagnetik tanpa mengganggu atau diganggu oleh peralatan lain. Saat ini, kesesuaian produk elektromagnetik terhadap standar EMC menjadi penting untuk mengatasi persyaratan wajib yang ditentukan oleh pasar global. Kesesuaian produk terhadap EMC menjadi bagian utama dari jaminan mutu dan keamanan produk-produk berkualitas. Makalah ini menyajikan kondisi saat ini (state-of-the-art). Kesesuaian EMC suatu produk di Indonesia terhadap peraturan dan sudut pandang teknis. Telah dilakukan survei mengenai peraturan EMC di Indonesia dengan berkomunikasi dengan beberapa badan pemerintah. Pada saat yang sama, diselidiki pula kesesuaian EMC beberapa produk seperti televisi dan refrigerator di pasar domestik dengan melakukan pengujian EMC untuk beberapa parameter emisi dan immunity. Dari hasil investigasi tersebut, perlu disadari bahwa peraturan EMC yang belum ada, dikarenakan kementerian yang bertanggung jawab belum mewajibkan. Oleh karena itu kesesuaian produk terhadap EMC masih belum wajib baik produk yang diproduksi atau diimpor untuk pasar domestik. Namun, direncanakan pemberlakuan wajib paling cepat pada tahun 2015. Selain itu, pengujian EMC menunjukkan bahwa produk yang diuji sebagian besar tidak sesuai dengan standar EMC. Produk-produk tersebut tidak memenuhi, salah satu dari emisi atau persyaratan imunitas atau bahkan keduanya. Fakta ini menekankan perlunya segera membuat peraturan EMC serta lembaga yang bertanggung jawab.
\end{abstract}

Kata kunci: kompatibilitas elektromagnetik, kesesuaian, gangguan/interferensi, keamanan

\begin{abstract}
Electromagnetic compatibility (EMC) can be considered as the ability of the electromagnetic apparatus to function satisfactorily without interfering the others or being interfered by the others. Nowadays, the conformity of electromagnetic products to corresponding EMC standards becomes of importance in order to cope with the mandatory requirements prescribed by the global market. The EMC conformity becomes the main part of quality assurance and safety of products. This paper presents the state-of-the-art EMC conformity of products in Indonesia from regulation and technical point of view. Survey on the quo-vadis of EMC regulation in the country by communicating with some governmental bodies has been conducted. At the same time, the EMC conformity of some products i.e. television and refrigerator in domestic market by conducting EMC testing on them including emission and immunity test was investigated. It is realized that regulations on EMC are not established yet because the responsible authorities has not assigned yet. Therefore, EMC conformity is not mandatory yet for manufactured or imported products in domestic market. However, mandatory standard of EMC will be implemented in earliest 2015. Moreover, EMC testing showed that the products under testing are mostly not conforming to EMC standards. Those products did not meet, either emission/immunity requirements or both. This fact emphasizes the need of establishing mandatory EMC regulation as well as responsible authorities.
\end{abstract}

Keywords: electromagnetic compatibility, conformity, interference, safety 


\section{INTRODUCTION}

Electronic industries in Indonesia play an important role in boosting national economic growth. Although they ranks in third place in terms of contribution to export in industrial sector, but their export growth increases yearly most significantly among others [1]. In 2009 there are totally 250 electronic companies with export volume of US\$ 6.35 billion. They produce electronic device for household purposes, not only intended for international market, but also for domestic market in the country. In 2008 their supply meets mostly $90 \%$ of domestic market demand of seven main household products, such as television, refrigerator, etc [2].

Nowadays, electronic products sold in domestic market are not mandatory to conform to either national or international EMC standards for household products. This adverse condition puts the technical requirement related to EMC conformity of the products in question.

In this paper we investigate the state-ofthe-art EMC conformity of products in Indonesia from regulation and technical point of view. We would like to realize the quality of EMC conformity of household products widely used in the country to international EMC standard in relationships with the role of the corresponding regulation.

The paper is organized as follows: we discuss the brief history of EMC in Indonesia, which leads to the description of the state-of-theart EMC regulation, the basics of EMC concept is highlighted and we introduce technical assessment and some results from EMC testing of two electronic household products considered as representative main products in the country. And also we discuss the necessity of mandatory status of EMC regulation for EMC conformity of products.

The history of EMC in Indonesia dates back to early 80's as the Indonesian National Standardization Body (BSN) began to develop EMC standardization and encourage the establishment of EMC testing center. This development sparked also the interests of the society from academic body (Institut Teknologi Bandung), governmental bodies (LIPI, The Ministry of Communication and Information and The Ministry of Industry) and state company (Sucofindo).

The development of EMC testing was started with the testing of electrical safety and reliability of electric apparatus. As the global awareness on EMC conformity of products increases, the electronic manufacturers in the country were encouraged to get EMC marking upon their export products as required by the global market.

The first EMC testing for safety purpose, such as burst, ESD, was commercially conducted by a testing company Sucofindo in early 2000 . The testing also took place in the new established semi anechoic chamber in Indonesia Aircraft Industry (IPTN). The further EMC testing facilities were established in Research Centers and Technology Quality system testing (P2SMTP LIPI) and B4T of The Ministry of Industry with research and commercial purposes, respectively.

As BSN is still working with the development of national EMC standardization, none of governmental bodies was concerned with the development of EMC regulation and its implementation as well. This lack of EMC regulation is of course leading to adverse condition from technical as well as economical point of view.

The mandatory for EMC conformity on national EMC standard becomes of indispensible importance to be applicable in the near time to cope with the upcoming international and regional trade treaties, such as Technical Barriers to Trade - World Trade Organization (TBTWTO), ACFTA (Asian-China Free Trade Area), ASEAN Harmonized Electrical and Electronic Equipment Regulatory Regime (AHEEERR) and Asean Economic Community (AEC).

In order to strengthen the national product competitiveness upon global level, a systematical scheme defining the functionality of stakeholders should be proposed. We consider The Ministry of Information and Communication as the authority producing the regulation, which is based on the national standard developed by BSN. The Ministry of Industry enforces the regulation to the industries and act as supervisor. Some companies provide technical services to assure products conform to the standard in order to hold with the regulation.

\section{EMC CONCEPT \& TECHNICAL ASSESSMENT}

To achieve reliable products conforming to EMC standard, EMC concept should be taken into consideration as part of design framework. 
Electromagnetic compatibility itself can be defined as the ability of electrical apparatus to function satisfactorily in its electromagnetic environment without disturbing intolerably other apparatus in that environment [4].

The disturbance mechanism in EMC concept can be modeled as follow:

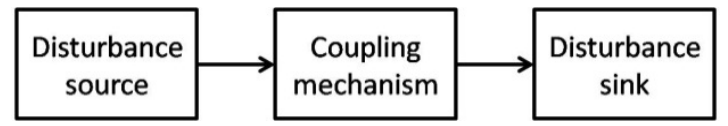

Figure 1. Disturbance Model of EMC

From EMC point of view, the product can be considered as disturbance source and in the same time, as disturbance sink. As disturbance source it may emit disturbance effect conductively or radiatively to the environment. Conversely, as disturbance sink, it may suffer from disturbance effect of other. To assure its electromagnetic compatibility, the product is subject to EMC testing according to EMC standards $[5,6]$. Its emission and immunity level become the focus of the testing.

We conducted technical assessment on EMC conformity of products by running testing on two household products, i.e. television and refrigerator. Both products are considered as of most widely used household products in the country and therefore, their representation on household products is statistically applicable. As product sample, two types of television from 14 manufacturers are taken into consideration, i.e. traditional CRT type and modern LCD type. While the testing of refrigerator involved the products from 6 manufacturers. From statistical point of view, the number of samples can be considered as representative because those devices under test represent $52 \%$ and $54 \%$ of television and refrigerator manufacturer in the country.

From brand level point of view, the television manufacturers under test consist of 4 national brands and 6 international brands, while all refrigerator manufacturers under test are coming from national brand. The consideration on brand level is of interests because the awareness of international brand on EMC conformity of product supported by its relative higher technology cutting-edge should be presumably higher than that of national brand.
In general, the conducted and radiated EMC testing includes emission test and immunity test. Both testing takes 7 test parameter and 9 test parameter in case of television and refrigerator, respectively [3]. Voltage dip immunity is not included in the refrigerator test. All test parameter are examined repeatedly in three times, except radiated emission and immunity due to relative long testing duration. The result of all EMC testing on each device under test is declared by passed or failed according to the applicable standard [4].

\section{EXPERIMENTAL RESULTS AND EXPLANATION}

Here, the results of EMC testing are presented. To give the sense of product conformity to the standard, some visualized results from emission test are given. In Figure 1 the spectrum of typical failed radiated emission test on a television is depicted. The failure occurs at lower frequency region, in which the emitted interference peak exceeds the compatibility level of EMC standard. Conversely, the spectrum in Figure 2 shows passed radiated emission test on other television.

A relative severe condition occurred in radiated emission from refrigerator (see Figure 3). Although lower spectral density, but several peaks exceeding the compatibility level of EMC standard exist at lower frequency region.

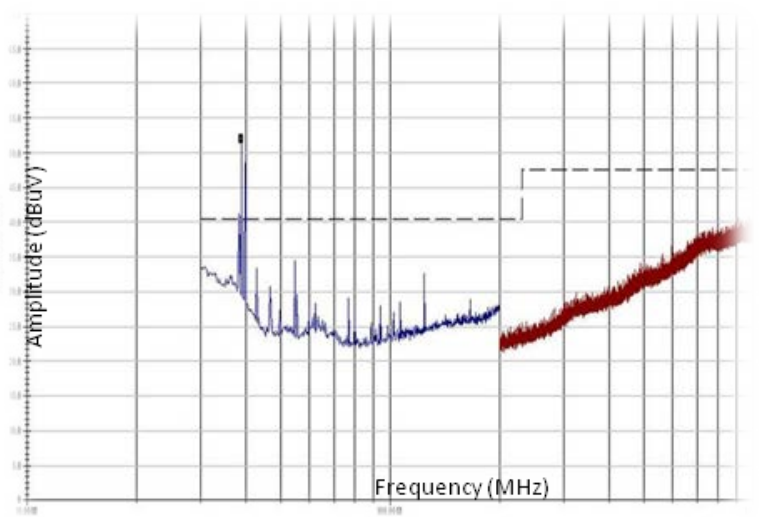

Figure 1. Radiated Emission of Television in Failed Status 


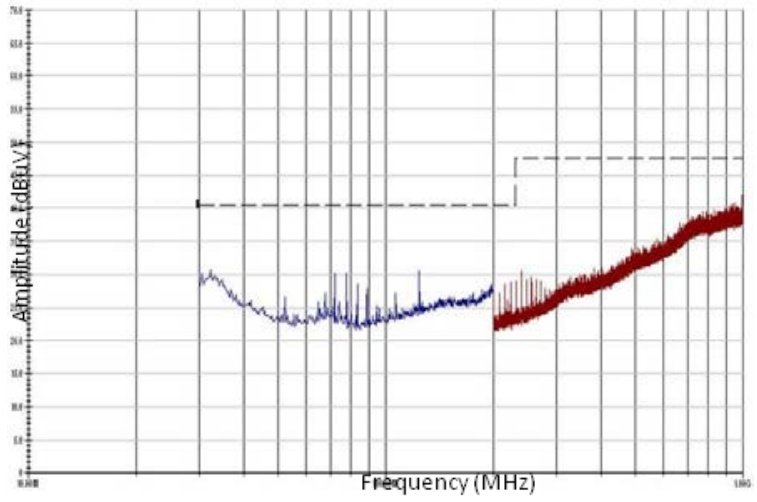

Figure 2. Radiated Emission of Television in Passed Status

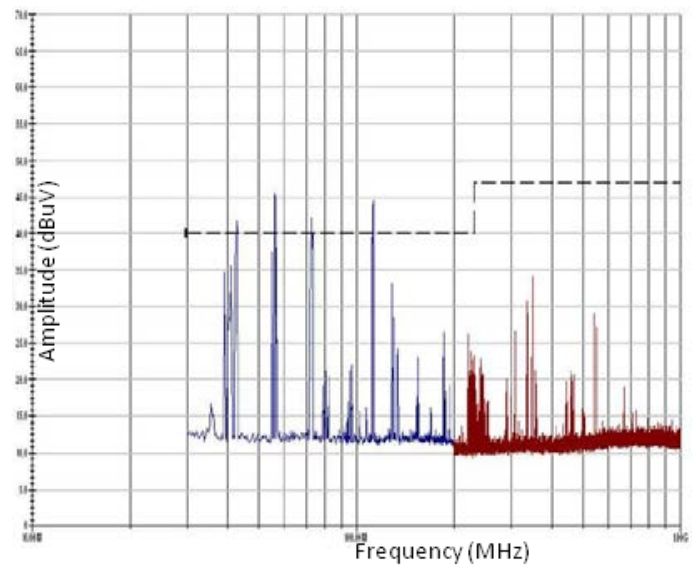

Figure 3. Radiated Emission of Refrigerator

Figure 4 presents the spectrum of failed conducted emission test on television. Some emitted peaks of spectrum are exceeding the compatibility level of EMC standard at lower frequency and higher frequency.

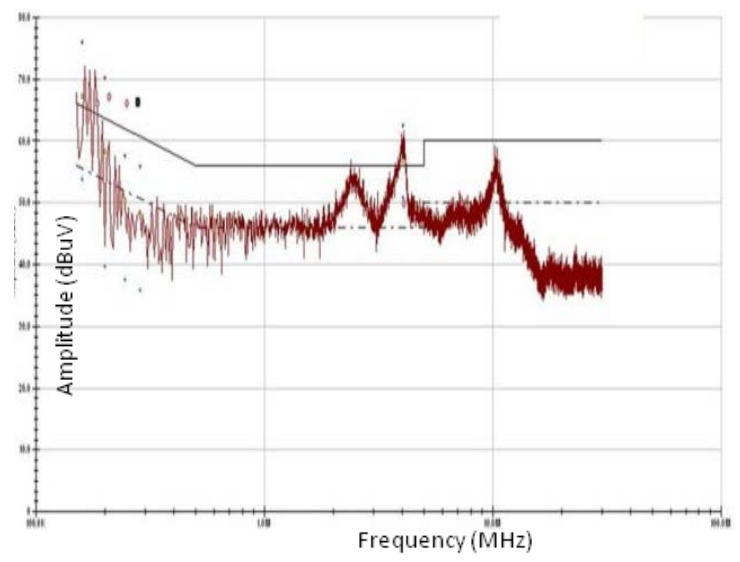

Figure 4. Conducted Emission of Television in Failed Status
The EMC testing is completely summarized in the following tables by so-called compatibility rate, which is defined as the ratio of manufacturers passing the testing to all examined ones.

In case of television, either CRT or LCD types passed not all emission tests as shown in Table 1. They passed only disturbance voltage at antenna. In immunity test only LCD type shows its superiority, while CRT type is only immune to ESD test (see Table 2).

As the EMC standard requires passed status for each parameter test, it may be concluded that in overall all manufacturers of television are failed in EMC conformity of their products.

Table 1. Emission Test on Television

\begin{tabular}{llccc}
\hline & \multicolumn{2}{c}{ Test parameter } & \multicolumn{2}{c}{$\begin{array}{c}\text { Compatibility } \\
\text { rate (\%) }\end{array}$} \\
\hline 1 & $\begin{array}{l}\text { DeT } \\
\text { Disturbance voltage } \\
\text { mains terminal }\end{array}$ & 0 & 0 \\
2 & $\begin{array}{l}\text { Disturbance voltage at } \\
\text { antenna }\end{array}$ & 100 & 100 \\
3 & $\begin{array}{l}\text { Disturbance } \\
\text { emission }\end{array}$ & power & 0 & 0 \\
4 & Radiated emission & 30 & 0 \\
\hline
\end{tabular}

Table 2 Immunity Test on Television

\begin{tabular}{clcc}
\hline & \multicolumn{2}{c}{ Test parameter } & \multicolumn{2}{c}{$\begin{array}{c}\text { Compatibility } \\
\text { rate (\%) }\end{array}$} \\
& \multicolumn{2}{c}{ CRT } & LCD \\
\hline 1 & $\begin{array}{l}\text { Electric } \\
\text { transient/burst immunity }\end{array}$ & 0 & 100 \\
2 & $\begin{array}{l}\text { Electrostatic discharge } \\
\text { immunity }\end{array}$ & 100 & 100 \\
3 & Radiated immunity & 0 & 100 \\
\hline
\end{tabular}

In case of refrigerator, in general the compatibility rate EMC is relative better in comparison with that of television. All manufacturers passed all EMC testing, except radiated emission test. None of manufacturers passed this test. In spite of only one failed test, it may be concluded that none of manufacturers of refrigerator is conform to the EMC standard. 
Table 3. Emission Test on Refrigerator

\begin{tabular}{llc}
\hline No & \multicolumn{1}{c}{ Test parameter } & $\begin{array}{c}\text { Compatibility rate } \\
\text { (\%) }\end{array}$ \\
\hline 1 & Disturbance voltage & 100 \\
2 & Disturbance power & 100 \\
3 & Discontinuous & 100 \\
& disturbance & \\
4 & Radiated emission & 0 \\
\hline
\end{tabular}

Table 4. Immunity Test on Refrigerator

\begin{tabular}{llc}
\hline No & \multicolumn{1}{c}{ Test parameter } & $\begin{array}{c}\text { Compatibility rate } \\
(\%)\end{array}$ \\
\hline 1 & Conducted immunity & 100 \\
2 & EFT/burst immunity & 100 \\
3 & ESD immunity & 100 \\
4 & Surge immunity & 100 \\
5 & Voltage dip & N/A \\
& immunity & \\
6 & Radiated immunity & 100 \\
\hline
\end{tabular}

\section{CONCLUSIONS}

This paper presents the fact of the level of EMC conformity of widely used electronic product in Indonesia. In overall, none of the products assessed conform to the EMC standard. This adverse condition is reasonable because of the lack of EMC regulation in the country. Therefore, the establishment of EMC regulation and its mandatory enforcement by the authorities become compulsory to ensure the EMC conformity of the products. In consumer level, this could lead to better protection from adverse effect of bad-quality products.

\section{ACKNOWLEDGEMENT}

Thanks to Head of B4T, and Head of Standardization providing us with the facilities for investigation, testing and also to Mr. Djoko Darwanto and Mr. Deny Hamdani from Electrical Engineering ITB for their corrections, and also all to all of friends in the Laboratory of
Electronics and EMC of B4T for good cooperation.

\section{REFERENCES}

[1] Ministry of Industry of Indonesia Republic, 2013, Data of Directorate of Electronics.

[2] A.J. Schwab., 1990, Electromagnetic Compatibility.

[3] CISPR, 2009, Requirement for Household Appliances, Elect. Tool, and Similar Apparatus. Part 1 Emission. 14-1 Ed.5.1.

[4] CISPR, 2009, Requirement for Household Appliances, Elect. Tool, and Similar apparatus. Part 2 Immunity-product family standard 14-2 2008 Emission. 14-1 Ed.5.1.

[5] CISPR, 2009, Sound and Televison Broadcast Receiver and Associated Equipment-Radio Disturbance Characteristics Limit and Method of Measurement. 13 Ed.5.

[6] CISPR, 2006, Sound and Televison Broadcast Receiver and Associated Equipment-Immunity Charasteristics Limit and Methods of Measurement, 20 Ed.6.

[7] D.Djoko \& H.Deny, 2010, Kompatibilitas Elektromagnetik, ITB.

[8] D.Djoko \& H.Deny, 2010, Proteksi Petir berbasis EMC, Electromagnetic Compatibility, ITB. 